\title{
ANALYSIS OF METHYLDOPA THERAPY ON SFIt-1 ANTIANGIOGENIC LEVELS IN PATIENTS WITH SEVERE PREECLAMPSIA
}

\author{
Teri Wina Herwati ${ }^{1}$ Yulistiani ${ }^{2}$, Eddy Zarkaty $\mathbf{M}^{3}$ \\ ${ }^{1}$ Master Program of Clinical Pharmacy, ${ }^{2}$ Department of Clinical Pharmacy, Faculty of Pharmacy, Universitas \\ Airlangga, ${ }^{3}$ Department of Obstetrics, Haji Hospital, Surabaya
}

\begin{abstract}
ABSTRAK
Metildopa merupakan obat lini pertama untuk mengobati hipertensi pada kehamilan yang bekerja pada reseptor a2-adrenergik. Selain di sistem saraf pusat, reseptor a2-adrenergik juga banyak ditemukan di sel trofoblas plasenta. Metildopa menghambat pembentukan adenylyl cyclase yang berakibat pada penurunan produksi kadar antiangiogenik sFlt-1. Penelitian ini merupakan penelitian prospektif observasional dengan desain penelitian cross-sectional yang melibatkan pasien preeklampsia berat di Instalasi Ruang Bersalin RSU Haji Surabaya. Pengamatan kadar antiangiogenik sFlt-1 diukur sebelum dan sesudah 48 jam (minimal 2 hari) mendapatkan terapi metildopa dengan dosis $3 \times 250 \mathrm{mg}$ atau $3 \times 500 \mathrm{mg}$ sehari. Dari hasil penelitian diperoleh 19 pasien yang memenuhi kriteria inklusi, menunjukkan adanya penurunan kadar antiangiogenik sFlt-1. Rerata kadar sFlt-1 pada 13 pasien

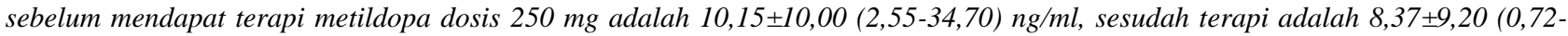
9,20) $\mathrm{ng} / \mathrm{ml}$ dengan persentase penurunan kadar sFlt-1 17,54\%. Sedangkan rerata kadar sFlt-1 pada 6 pasien sebelum mendapat

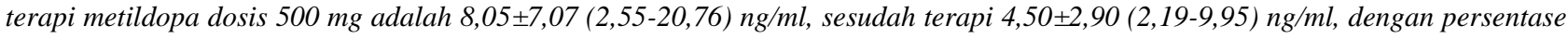
penurunan 44,10\%. Terapi metildopa dosis $500 \mathrm{mg}$ memberikan persentase efek penurunan kadar sFlt-1 lebih besar dibandingkan dengan pemberian terapi metildopa dosis $250 \mathrm{mg}$. Pemberian terapi metildopa pada pasien PEB dapat menurunkan kadar sFlt-1, dengan penurunan 17,54\% pada pemberian terapi metildopa dosis $250 \mathrm{mg}$ dan 44,10\% pada dosis $500 \mathrm{mg}$. (FMI 2018;54:46-52)
\end{abstract}

Kata kunci: Metildopa; preeklampsia berat; antiangiogenik; soluble fms-like tyrosine kinase (sFlt-1)

\begin{abstract}
Methyldopa is the first-line drugs to treat hypertension in pregnancy. It can decrease blood pressure in preeclampsia by affecting a2adrenoreceptors in central nervous system. However, it could also act by decreasing production of sFlt-1 antiangiogenic protein levels involved in the pathophysiology of hypertention in preeclampsia. The purpose of this study was to analyze methyldopa therapy on sFlt-1 antiangiogenic levels in the plasma of pregnant women with severe preeclampsia at the Obstetric Departement, Haji Hospital, Surabaya. This was a prospective study with observational cross-section study design. The sFlt-1 angiogenic levels were observed before and after (48 hours) methyldopa administration in severe preeclampsia patient with or without complications in the period of August to October 2016. Patient received methyldopa $250 \mathrm{mg}$ or $500 \mathrm{mg}$, three times a day for clinical indications according a standard protocol. The study was approved by the ethical committee of Haji Hospital, Surabaya. There were 19 patients with preeclampsia who met the inclusion criteria, showed a decrease in the levels of sFlt-1 before and 48 hours after methyldopa therapy. Levels of sFlt-1 before methyldopa therapy in a dose of $250 \mathrm{mg}$ was $10.15 \pm 10.00$ (2.55-34.70) $\mathrm{ng} / \mathrm{ml}$ and after therapy $8,37 \pm 9,20(0.72-9.20) \mathrm{ng} / \mathrm{ml}$, with a percentage decrease $17.54 \%$. sFlt-1 levels before methyldopa therapy in a dose of $500 \mathrm{mg}$ was $8.05 \pm 7.07(2.55-20.76) \mathrm{ng} / \mathrm{ml}$, after therapy $4.50 \pm 2.90(2.19-9.95) \mathrm{ng} / \mathrm{ml}$, with a percentage decrease $44.16 \%$. Methyldopa therapy could decrease sFlt-1 levels of antiangiogenic factor in patients with severe preeclampsia. (FMI 2018;54:46-52)
\end{abstract}

Keywords: Methyldopa; severe preeclampsia; antiangiogenic; soluble fms-like tyrosine kinase (sFlt-1)

Correspondence: Teri Wina Herwati, Jl. Kenanga 105B, Polorejo, Babadan, Ponorogo, Indonesia.

Phone: 082231133662. Email: terry.wiena.almeera@gmail.com

\section{INTRODUCTION}

Preeclampsia is a syndrome that affects $5-10 \%$ of obstetric pregnant women and still the major cause of morbidity as well as maternal and perinatal mortality in developing countries (Maynard 2003). Preeclampsia is a pregnancy-specific syndrome in the form of reduced organ perfusion due to vasospasm and endothelial activation, which is characterized by increased blood pressure $=160 / 110 \mathrm{mmHg}$ and proteinuria over $5 \mathrm{~g} / 24$ hours or 4+ in a qualitative assay, occurs in pregnancy over 20 weeks (Angsar 2010, Cunningham et al 2010).

More recently, there is a hypothesis that maternal imbalance in preeclampsia is due to a pathogenic role of angiogenesis. Antiangiogenic factors and proangiogenic are known to play an important role in the pathophysiology of preeclampsia. In the state of preeclampsia there is an imbalance of antiangiogenic and proangiogenic factors which occurred about 4-5 weeks 
before the clinical manifestation of preeclampsia emerge (Levine et al 2004, Maynar 2003). High sFlt-1 anti-angiogenic factors levels and low VEGF proangiogenic factor secreted by the placenta contribute to the development of maternal hypoxia syndrome, that ensued state of hypertension in preeclampsia, and to the fetal growth. Soluble Flt-1 is a variant of the VEGF receptor 1 (Flt-1) which is produced by the placenta and acts by neutralizing a protein proangiogenic VEGF and placental growth factor PIGF act by blocking the interaction with its receptor. VEGF and P1GF the vascular endothelial growth factor are key molecules in angiogenesis and vasculogenesis, particularly during embryogenesis (Maynard 2003).

Methyldopa is the first-line drugs to treat hypertension in pregnancy, a anti-adrenergic group, which acts on a2adrenergic receptors, exerting an anti-hypertensive effect, especially in the central nervous system (Day et al 1973, Henning \& Rubenson 1970). However, it can also act by reducing the production of antiangiogenic protein that is involved in the pathophysiology of hypertension and proteinuria in preeclampsia. a2adrenoceptor is also been identified in a variety of other human tissues outside the CNS (Central Nervous System), including in the myometrium and the placenta, especially in the trophoblast (Falkay \& Kovacs 1994). a2-adrenoceptor stimulating effect which universally occurs is the inhibition of adenylyl cyclase which leads to a decrease in production of cAMP. cAMP has proved to be a stimulating strong inducer of Flt-1. The acts mechanism of methyldopa in decreased levels of antiangiogenic factors sFlt-1 is the stimulation of a2-adrenoceptor that inhibits adenylyl cyclase, resulting in a decrease in cAMP (which is an inducer strong of Flt-1) production and finally the decrease of sFlt-1 expression (Hattori 2007, Kahlil et al 2008, Zhang et al 2012). The purpose of this study was to analyze the levels of antiangiogenic sFtl-1 before and after getting methyldopa therapy in patients who underwent PEB conducted in department of Obstetrics and Gynecology, Haji Hospital, Surabaya.

\section{MATERIALS AND METHODS}

This was a prospective study with observational crosssectional design, involving patients with severe preeclampsia in August-October 2016 at the Department of Obstetrics, Haji Hospital, Surabaya. The number of samples were taken by numerical calculation of analytical studies paired with the calculation results, obtaining 19 patients. Inclusion criteria for this study were patients diagnosed with PEB with or without complications by clinical symptoms and laboratory, patients receiving methyldopa dose of $3 \times 250 \mathrm{mg}$ or a dose of $3 \times 500 \mathrm{mg}$ daily for 48 hours (minimum 2 days), single or double pregnancy and a living fetus, willing to participate in the study and signed informed consent. Exclusion criteria were patients receiving methyldopa of early pregnancy, and patients diagnosed with postpartum PEB. Drop out criteria were the PEB patients who met the inclusion criteria, but suffered the adverse reaction to methyldopa during therapy, and patients who withdrew during the study. The measurement of study variables was performed by the clinical pathology laboratory, Tropical Disease Center, Surabaya. Method used for measuring the levels of sFlt1 was ELISA.

Blood samples were taken from patients who met the inclusion criteria. This was taken before and after (48 hours/at least 2 days) methyldopa administration and subsequent measurement of the levels of sFlt-1. Blood samples of the subjects were taken using a tube containing with heparin or $1 \mathrm{ml}$ EDTA, centrifuged for 10 minutes at 3000 RPM after 30 minutes since sample was taken. Furthermore, plasm samples were stored at $-80^{\circ} \mathrm{C}$. The observation of $\mathrm{sFt}-1$ antiangiogenic levels was then carried out.

\section{Data analysis and statistics}

Descriptive analysis was performed to determine the demographic data of preeclampsia patients before and after methyldopa therapy. To determine the differences in the levels of patient sFlt-1 profile before and after therapy, data analysis steps were used. Data distribution test was performed with SPSS instrument to assess whether the data distribution was eligible or not. If data distribution was eligible (normally distributed), paired ttest was used. Whereas, if data distribution was not eligible (not normally distributed), the transformation of data was carried out. If the new variable transformed normal distribution, paired t-test was used. However, if the new variable transformation result was not normal, Wilcoxon test was used.

\section{RESULTS}

During 3 months of observation in the Department of Obstetrics, Haji Hospital, Surabaya, we found 19 patients who met the inclusion criteria, then divided into 2 groups. Total of 13 patients were received therapy of methyldopa $3 \times 250 \mathrm{mg}$ daily, and 6 patients were received 3x500 mg methyldopa therapy daily.

Patients' demographics and characteristics are shown in Table 1. Distribution of systolic blood pressure 160 $\leq 170 \mathrm{mmHg}$ was $26.3 \%$, and diastolic blood pressure $<110 \mathrm{mmHg}$ was $57.9 \%$. Seven patients had proteinuria 
+4 with a percentage of $36.8 \%$. The gestational age of patients in this study was $36-40$ weeks, whereas the age of the patients who entered the study demonstrated the productive age, ranging from 25 to 34 years, as many as 10 patients with a percentage of $52.6 \%$. The number of patients $>35$ years old was 7 patients with a percentage of $36.8 \%$. The percentage of patients experiencing edema was $63 \%$, and 7 patients were not obtained edema with a percentage of $37 \%$.

Test results of antiangiogenic sFlt- 1 levels by ELISA at a wavelength of $450 \mathrm{~nm}$ in 19 patients showed decreased levels of sFlt-1 after the administration of methyldopa therapy at a dose of either $250 \mathrm{mg}$ or $500 \mathrm{mg}$. In patients treated with a dose of $250 \mathrm{mg}$ methyldopa, the results showed mean score of $10.15 \pm 10.00 \mathrm{ng} / \mathrm{ml}$ and the levels after methyldopa treatment was $8.37 \pm 9.20$ $\mathrm{ng} / \mathrm{ml}$. The administration of $250 \mathrm{mg}$ methyldopa provided varying levels of sFlt-1 in plasma which was significant with $\mathrm{p}=0.001$ by reduction percentage of $17.54 \%$. Whereas, the average level of sFlt-1 in group which was treated with $500 \mathrm{mg}$ methyldopa before treatment was $8.053 \pm 7.075 \mathrm{ng} / \mathrm{ml}$ and after treatment was $4.50 \pm 2.90 \mathrm{ng} / \mathrm{ml}$. The administration of $500 \mathrm{mg}$ methyldopa provided varying levels of sFlt-1 in plasma which was not significant with $\mathrm{p}=0.226$ with a percentage of $44.10 \%$ decline. These results are shown in Table 2 and Fig. 1.

\section{DISCUSSION}

Preeclampsia becomes one of the most complex disorders in pregnant mother. The demographic data (Table 1) related to the age of the patients who entered the study showed the productive age, ranging from 25-34 years as many as 10 patients with a percentage of $5.6 \%$. The number of patients with more than 35 years old was 7 patients with a percentage of $36.8 \%$. Mother with age more than 35 years is at risk of preecampsia. With increasing age, the stiffness of the arteries will increase, and the blood vessel wall structural changes can also affect the elasticity of blood vessels in pregnant women (Hasibuan \& Aminudin 2012)

Table 1 showed demographic data distribution percentage of systolic blood pressure $160-\leq 170 \mathrm{mmHg}$ as much as $26.3 \%$, and diastolic blood pressure $<110$ $\mathrm{mmHg}$ as much as $57.9 \%$. Diastolic pressure describes the peripheral resistance, while the systolic pressure describes the massive outpouring of the heart. Increased blood pressure in patients with preeclampsia was caused by the failure of the invasion of trophoblast cells in the muscle layer of the spiral arteries and tissue surrounding the matrix. Muscle layer spiral arteries became rigid and hard fixed so that the lumen of the spiral arteries did not allow distends and vasodilation. As a result, the spiral arteries were relatively less vasoconstrictive, and there was a failure in 'remodeling of the spiral arteries', so the uteroplacental blood flow decreased, and there was hypoxia, ischemia of the placenta that ensued hypertension (Angsar 2010). Blood pressure measurements were routinely used in antenatal care to detect or predict hypertension.

Fifteen patients had proteinuria. A total of 7 patients had proteinuria +4 with a percentage of $36.8 \%$ (Table 1). Changes in urinary system in pregnancies resulted in increased renal size of $15 \mathrm{~cm}$, so the glomerular filtration rate and renal plasma flow increased. GFR increased by $50 \%$ in the second trimester so as to increase the frequency of discharge of urine. Proteinuria is one of the clinical symptoms of preeclampsia, which is caused by circumstances which result in endothelial dysfunction of glomerular changes. Endotheliasis has impact on increasing the permeability of the basement membrane, as well as their protein leakage lysis of filtration (Angsar 2010).

Increased sFlt-1 levels before and after methyldopa therapy of preeclampsia, due to the abnormality of trophoblast invations, triggers placental ischemia. Placental ischemia causes the spiral arteries to become narrowed and blood flow to the placenta decreases. There are imbalances of antiangiogenic factors of sFlt- 1 and VEGF pro-angiogenic, followed by the release of endothelial dysfunction soluble inflammatory cytokines Endoglin (zinc) and TGF-ß. Results from endothelial cell dysfunction include decreased prostacyclin, nitric oxide production, and procoagulant protein release (Davison 2004, Maynard et al 2003)

Methyldopa therapy decreased the levels of sFlt-1 in patients with preeclampsia, which was in accordance with a previous study by Kahlil et al, (2008). Methyldopa in this study reduced the production of antiangiogenic protein that is involved in the pathophysiology of hypertension and proteinuria in preeclampsia (Kahlil et al 2008). Methyldopa was administered at a dose of 750-1500 mg/day. The mechanism of methyldopa in decreased levels of antiangiogenic factors sFlt-1 is the stimulation a2-adrenoceptor that inhibits adenylyl cyclase, resulting in a decrease in production of cAMP (which is an inducer strong of sFlt-1) and finally the expression of sFlt-1 decreases (Kahlil et al 2008). 
Table 1. Characteristics of Early Patients with Severe Preeclampsia

\begin{tabular}{|c|c|c|c|}
\hline \multirow[b]{2}{*}{ Characteristics } & \multicolumn{2}{|c|}{ Total patient $(\mathrm{n}=19)$} & \multirow[b]{2}{*}{ Mean \pm SD } \\
\hline & Amount (n) & $\begin{array}{c}\text { Percentage } \\
(\%)\end{array}$ & \\
\hline \multicolumn{4}{|l|}{ Mother age (years) } \\
\hline $20-24$ & 2 & 11 & \multirow{5}{*}{$32 \pm 6$} \\
\hline $25-29$ & 5 & 26 & \\
\hline $30-34$ & 5 & 26 & \\
\hline $35-39$ & 4 & 21 & \\
\hline$\geq 40$ & 3 & 15 & \\
\hline \multicolumn{4}{|l|}{ Gravidity } \\
\hline Primigravida & 18 & 95 & \\
\hline Multigravida & 1 & 5 & \\
\hline \multicolumn{4}{|l|}{ Pregnancy age (week) } \\
\hline $36-<37$ & 9 & 47 & \multirow{4}{*}{$37 \pm 1$} \\
\hline $37-<38$ & 6 & 32 & \\
\hline $38-<39$ & 1 & 5 & \\
\hline $39-<40$ & 3 & 16 & \\
\hline \multicolumn{4}{|c|}{ PEB is diagnosed when blood pressure $(\mathrm{mmHg})$} \\
\hline \multicolumn{4}{|c|}{ Sistolic } \\
\hline$<160$ & 3 & 16 & \multirow{6}{*}{$171 \pm 20$} \\
\hline $160-<170$ & 5 & 26 & \\
\hline $170-<180$ & 4 & 21 & \\
\hline $180-<190$ & 4 & 21 & \\
\hline $190-<200$ & 1 & 5 & \\
\hline$\geq 200$ & 2 & 11 & \\
\hline \multicolumn{4}{|l|}{ Diastolic } \\
\hline$<110$ & 11 & 58 & \multirow{3}{*}{$109 \pm 22$} \\
\hline $110-<120$ & 3 & 16 & \\
\hline$\geq 120$ & 5 & 26 & \\
\hline MAP (Mean Arterial Pressure): PRE & 19 & 100 & $129 \pm 20$ \\
\hline Edema $(+)$ & 12 & 63 & \\
\hline Edema (-) & 7 & 37 & - \\
\hline \multicolumn{4}{|l|}{ Proteinuria } \\
\hline Negative (-) & 4 & 21 & \multirow{5}{*}{ - } \\
\hline$+1(25 \mathrm{mg} / \mathrm{dL})$ & 2 & 11 & \\
\hline$+2(75 \mathrm{mg} / \mathrm{dL})$ & 5 & 26 & \\
\hline$+3(150 \mathrm{mg} / \mathrm{dL})$ & 1 & 5 & \\
\hline$+4(500 \mathrm{mg} / \mathrm{dL})$ & 7 & 37 & \\
\hline \multicolumn{4}{|l|}{ Methyldopa dose } \\
\hline $250 \mathrm{mg}$ & 13 & 69 & \multirow[t]{2}{*}{-} \\
\hline $500 \mathrm{mg}$ & 6 & 31 & \\
\hline \multicolumn{4}{|l|}{ Therapy } \\
\hline $250 \mathrm{mg}$ methyldopa & 2 & 10 & \multirow{4}{*}{-} \\
\hline $250 \mathrm{mg}$ methyldopa $+10 \mathrm{mg}$ nifedipin & 11 & 57 & \\
\hline $500 \mathrm{mg}$ methyldopa $+10 \mathrm{mg}$ nifedipin & 6 & 32 & \\
\hline MgSO4 & 19 & 100 & \\
\hline \multicolumn{4}{|l|}{ Another complaint } \\
\hline Dizzy & 4 & 21 & \\
\hline Blurred vision & 1 & 5 & - \\
\hline Itching all over the body & 1 & 5 & \\
\hline Out of breath & 1 & 5 & \\
\hline History KB & & & \\
\hline None & 12 & 63 & - \\
\hline Injection & 5 & 27 & - \\
\hline Pill & 2 & 10 & \\
\hline
\end{tabular}


Table 2. Profile of sFlt-1 levels before and after treatment with methyldopa in a dose of $250 \mathrm{mg}$ and 500 mg in PEB patients

\begin{tabular}{|c|c|c|}
\hline \multirow{2}{*}{$\begin{array}{l}\text { Patients' initial } \\
\text { (Gestational Age) }\end{array}$} & \multicolumn{2}{|c|}{$\begin{array}{c}\text { SFlt-1 levels (ng/mL) } \\
\text { Normal value *2.053 (0.895 to } 3.382) \mathrm{ng} / \mathrm{ml}\end{array}$} \\
\hline & Pre & Post \\
\hline \multicolumn{3}{|c|}{ Methyldopa $250 \mathrm{mg}$} \\
\hline $\begin{array}{c}\text { MS } \\
\text { (36 weeks) }\end{array}$ & 3.55 & 0.72 \\
\hline $\begin{array}{l}\text { HL } \\
\text { (36-37 weeks) }\end{array}$ & 5.56 & 3.20 \\
\hline $\begin{array}{c}\text { SZ } \\
(36-37 \text { weeks })\end{array}$ & 6.94 & 4.88 \\
\hline $\begin{array}{l}\text { MJ } \\
\text { (36-37 weeks) }\end{array}$ & 34.70 & 31.08 \\
\hline $\begin{array}{l}\text { WDY } \\
\text { (37 weeks) }\end{array}$ & 21.76 & 17.05 \\
\hline $\begin{array}{c}\mathrm{TS} \\
(37 \text { weeks })\end{array}$ & 4.40 & 2.70 \\
\hline $\begin{array}{c}\mathrm{AH} \\
(37 \text { weeks) }\end{array}$ & 3.93 & 3.17 \\
\hline $\begin{array}{l}\text { SMP } \\
\text { (37 weeks) }\end{array}$ & 3.64 & 3.58 \\
\hline $\begin{array}{c}\text { EJ } \\
\text { (37 weeks) }\end{array}$ & 6.56 & 5.55 \\
\hline $\begin{array}{l}\text { SMD } \\
\text { (37-38 weeks) }\end{array}$ & 5.55 & 4.40 \\
\hline $\begin{array}{c}\mathrm{SN} \\
(38 \text { weeks })\end{array}$ & 2.55 & 1.81 \\
\hline $\begin{array}{c}\mathrm{KN} \\
(39-40 \text { weeks })\end{array}$ & 23.56 & 21.73 \\
\hline $\begin{array}{c}\text { WDT } \\
(39-40 \text { weeks }) \\
\end{array}$ & 9.30 & 8.94 \\
\hline Mean \pm SD & $10.15 \pm 10.00$ & $8.37 \pm 9.20$ \\
\hline $\begin{array}{l}\text { Difference in pre and post } \\
\text { levels of sFlt-1 }\end{array}$ & \multicolumn{2}{|c|}{1.78} \\
\hline \% Decreased levels of sFlt-1 & \multicolumn{2}{|c|}{$\downarrow 17.54 \%$} \\
\hline Range & $2.55-34.70$ & $0.72-31.08$ \\
\hline \multicolumn{3}{|c|}{ Methyldopa $500 \mathrm{mg}$} \\
\hline $\begin{array}{c}\text { EM } \\
(36 \text { weeks })\end{array}$ & 3.11 & 2.19 \\
\hline $\begin{array}{l}\text { KS } \\
\text { (36-37 weeks) }\end{array}$ & 6.05 & 4.99 \\
\hline $\begin{array}{l}\mathrm{EF} \\
\text { (36-37 weeks) }\end{array}$ & 2.55 & 2.37 \\
\hline $\begin{array}{l}\text { SK } \\
(36-37 \text { weeks })\end{array}$ & 11.80 & 9.95 \\
\hline $\begin{array}{l}\text { SR } \\
(36-37 \text { weeks })\end{array}$ & 20.76 & 4.37 \\
\hline $\begin{array}{c}\text { IM } \\
(39 \text { weeks }) \\
\end{array}$ & 4.05 & 3.11 \\
\hline Mean \pm SD & $8.05 \pm 7.07$ & $4.50 \pm 2.90$ \\
\hline $\begin{array}{l}\text { Difference in pre and post } \\
\text { levels of sFlt-1 }\end{array}$ & \multicolumn{2}{|c|}{3.55} \\
\hline$\%$ Decreased levels of sFlt-1 & \multicolumn{2}{|c|}{$\downarrow 44.10 \%$} \\
\hline range & $2.55-20.76$ & $2.19-9.95$ \\
\hline
\end{tabular}




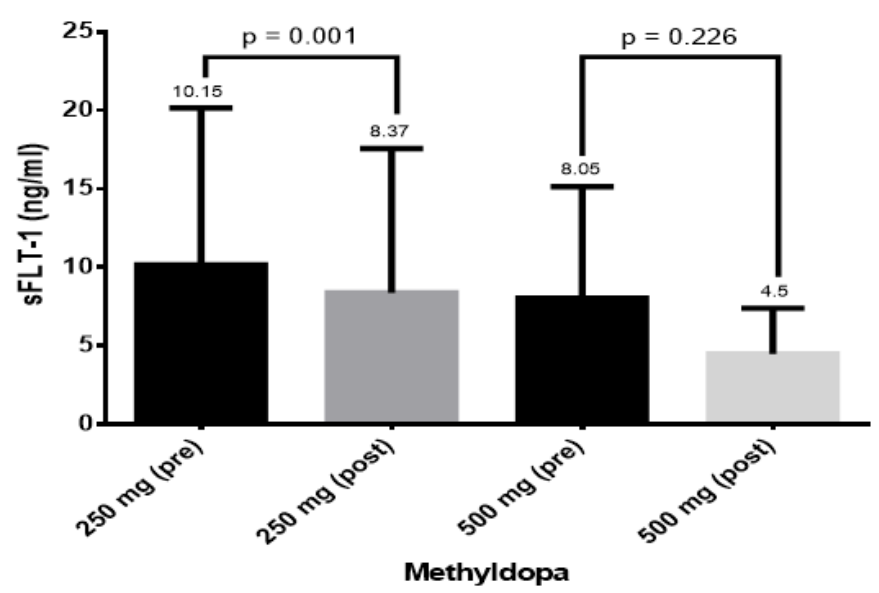

Fig. 1. Profile sFlt-1 before and after methyldopa therapy in patients PEB

Methyldopa role in the decreased levels of sFlt-1 is also demonstrated by the existence of the mechanism of action of methyldopa showed on the state of hypoxia in patients with preeclampsia, causing Hormone Growth Factor (HGF) activates protein Gs. The next Gs protein activates PKA, thus forming a bond HIF-1a/ $\beta$ by the enzyme PhDs. In addition, the Gs protein which binds to Adenylyl Cyklase will ATP to cAMP. This will cause PKA be activated to form estrogen. Estrogen plays a role in the activation of HIF-1a / $\beta$ in the process of formation of VEGF, sFlt-1, and others. With the metildopa acts in a2-adrenergic receptor that inhibits the formation of adenylyl cyclase the process of formation of Estrogen is interrupted, so that the process of formation of sFlt-1 is also disturbed or increased excess (Hattori et al 2007, Zhang et al 2012 ). The main active metabolite is alpha metilnorepinefrin, which resembles noreephinefrin impact. Presynaptic adrenoceptor stimulation in CNS leads to a decrease in central sympathetic outflow. This causes a decrease in blood pressure. a2adrenoceptor also been identified in various human tissues outside the CNS, including in the myometrium and the placenta, especially in trophoblast. a2-adrenoceptor stimulating effects were almost universal is the inhibition of adenylyl ciklase which leads to a decrease in production of cAMP. cAMP has been proved to be a stimulating strong inducer of Flt-1 (Zhang at al 2012).

The level of sFlt-1 affected the age of the mother's pregnancy, and the highest levels were found in gestational age from 37 weeks. So in this study, patients received methyldopa within 48 hours after delivery. This is based on previous studies, that the levels of sFlt-1 will drop within a short time after the delivery process as the main source of production of sFlt-1 in pregnancy is placenta (Maynar et al. 2003). sFlt-1 half-life is 3.4 hours (Wathen et al 2010). From the statistical test results, found no significant difference between the reduced levels of sFlt-1 with gestational age. This is caused by variations in the time of delivery by sampling as a sample before and after getting methyldopa therapy.

\section{CONCLUSION}

The use of antiangiogenesis methyldopa changed the levels of sFlt-1 in 19 patients with preeclampsia. In patients with PEB, the administration of methyldopa in a dose of $250 \mathrm{mg}$ and $500 \mathrm{mg}$ can reduce the levels of sFlt- 1 as much as $17.37 \%$ and $44.6 \%$.

\section{REFERENCES}

Angsar MD (2010). Hipertensi dalam kehamilan. In S. Prawirohardjo, Ilmu Kebidanan. Jakarta, PT. Bina Pustaka Sarwono Prawirohardjo, p 530-50

Cunningham F, et al (2010). Williams Obstetric. 23th ed. New York, McGraw-Hill Education

Davison J, et al (2004). New Aspects in Pathophysiology of Preeclampsia. Journal of the American Society of Nephrology 15, 2440-2448

Day MD, et al (1973). The mechanism of the a entihypertensive action of methyldopa in hypertensive rats. Eur J Pharmacol 21, 271-280

Hattori Y, Yamamoto S, Matsuda N (2007). Sympathetic control of VEGF angiogenic signaling. Circulation Research 101, 642-4

Henning M, Rubenson A (1971) Evidence that the hypotensive action of methyldopa is mediated by central actions of methylnoradrenaline. J Pharm Pharmacol 23, 407-11

Kahlil A (2008). Effect of antihypertensive therapy with alpha methyldopa on levels of angiogenic factor 
in pregnancies with hypertensive disorders. Plos ONE $6,5-21$

Levine RJ, et al (2004). Circulating angiogenic factors and the risk of preeclampsia. The New England Journal Medicine 350, 672-683

Maynard SE (2003). Excess placental soluble Fms-like tyrosine kinase 1 (sFlt-1) may contribute to endhotelial dysfunction, hypertension, and proteinuria I preeclampsia. $\mathrm{J}$ The Journal of Clinical Investigation $111,649-658$
Maynard SE, et al (2003). Soluble Fms-like tyrosine kinase 1 and endothelial disfunction in the pathogenesis of preeclampsia. Department of Medicine 57, 5

Zhang Z, et al (2012). Hypoxia-induce factor-1 alpha signaling: Regulation of vascular endothelial growth factor-dependent angiogenesis during ovarian corpus luteum development in mammals. Journal of Veterinary Medicine and Animal Health 4, 97-104 